\title{
Customer Orientation Management of Employees as Part of Value-Oriented Growth of Organization
}

\author{
Valeeva Yu.S. \\ University of Management «TISBI», \\ Kazan State Power Engineering University \\ Kazan, Russia \\ Valis2000@mail.ru \\ Bagrova E.A. \\ University of Management «TISBI» \\ Kazan, Russia \\ e-bagrova@mail.ru
}

\author{
Gatina E.A. \\ University of Management «TISBI» \\ Kazan, Russia \\ gatina_ea@mail.ru \\ Fedorova O.V \\ University of Management «TISBI» \\ Kazan, Russia \\ fiodorova_olga@rambler.ru
}

\begin{abstract}
This study is aimed at the scientific substantiation of theoretical and methodological approaches to the study of customer orientation exercised by retail chains and areas of respective management solutions.

The scope of study covers retail chains using methods of economic indicators comparative analysis. Despite the variety of theoretical and methodological approaches to the formation of customer and employee orientation in company management, theoretical and methodological provisions are necessary, including approaches to managing labor efficiency of retail chains, a personnel management system, which makes a customer-oriented approach happen taking into account the specifics of trade services. This paper describes an analysis done on Bakhetle, a regional chain and presents the predicted values according to the employees-oriented labor efficiency model proposed by the authors.

The paper defines the terms related to the concept of "customer orientation", offers aspects for how to manage the customer orientation of employees in retail chains based on the principle of authority and responsibility delegation. The methodology for assessing the labor efficiency of retail chains is presented in the format of a model of three main parameters (labor productivity, sale proceeds, and profit).

The development of retail services in Russia is widely discussed in theoretical and practical literature. However, Russian undertakings do not sufficiently apply the practice of foreign retailers aimed at optimizing costs and obtaining benefits from the influence of the retail chain. The purpose and objectives of the study arise out of the need to develop theoretical approaches and practical recommendations on how to increase the efficiency of retail companies and increase their competitiveness in the uncertain environment.
\end{abstract}

Keywords-customer orientation; value-oriented growth; services; retail chain.

\section{INTRODUCTION}

In modern business, companies engaged in building a stable competitive position increasingly move away from focusing on current sales figures and strive to develop longterm liaison with key market participants and, above all, customers. Close engagement with the client requires the coordination of targets, plans and business processes of partners, and also involves the establishment and maintenance of sustainable ties both at the organizational level and at the level of personal contacts. The company comes to creating sustainable competitive positions through building a system of partnerships that will make the process of creating and distributing value more efficient. Achievement of a stable competitive position requires a deeper understanding of customer orientation, and practical mechanisms for increasing customer orientation are becoming more popular.

A study run in Europe found that " $88 \%$ of actively involved employees believe that they can have a positive impact on the quality of the products produced by their companies as compared with $38 \%$ of employees who showed a low level of involvement; $72 \%$ of actively involved employees believe that they can have a positive impact on the quality of customer service as compared with $27 \%$ of employees who showed a low level of involvement" [1].

In this regard, the subject of employee orientation toward the client seems relevant both theoretically and in solving applied challenges.

The study is aimed at an approach to forming and building relations between the company with customers and employees as a source of increasing competitiveness. The core of the study is the processes of building and developing customer-oriented relationships. 


\section{LITERATURE REVIEW}

Current approaches to customer orientation of personnel can be split into two areas: Parasuraman, Zeithaml, Berry; Dabholkar, Sheperd, Thorpe who analyzed the importance of customer orientation on the quality of service provided, Kelley; Brown; Hennig-Thurau, Thurau; Donavan, Brown, and Mowen saw customer orientation of employees as a strategic factor in the success of the company.

A. Parasuraman, V. Zeithaml and L. Berry [Parasuraman, Zeithaml, Berry [2] developed the SERVQUAL model of evaluating the quality of service. Evaluation of factors refers to the characteristics of personnel behavior demonstrating the importance of its customer orientation as a key component of service quality.

The second group of scholars considered customer orientation as the basis for meeting needs, increasing loyalty, attracting and retaining customers and, consequently, improving the results of activities and the overall success of the company. The main model proposed by the scholars of the second group is the COSE (Customer Orientation of Service Employees) model. Kotler noted in 2006 in his writings that "every employee is a marketer" [3] implying that all employees of a company, regardless of which unit / department they work in, should focus on meeting the needs of consumers of those goods or services that this company produces.

Saxe, Weitz [4] were among the first to analyzed the performance of sales employees and assessed the activities of an individual employee on customer satisfaction through sales performance. The advantage of their approach is that they were able to correlate between the performance of employees with the requests and needs of consumers in the performance of sales department. This shows the role of the employee in the formation and provision of customer value. This concept is presented in the services marketing. It was described by Bateson [5], Berry [6]. Homburg [7], Brown [8], Kara [9] also demonstrated that customer-oriented employees can work more efficiently achieving better performance indicators and thereby increasing the level of sales of the company. Homburg indicated that there is a significant correlation between the customer orientation of the employees and the customer loyalty of the company. In his writings, Donovan [10] showed the statistical significance between the customer orientation of the employees and their satisfaction with their work, loyalty to the company in which they work, and organizational civil behavior.

Considering the category of customer orientation in relation to retail chains, it should be confirmed that the personnel is an important component, therefore, modern interpretations of customer orientation include the concept of internal customer orientation emphasizing the importance of not only the external client, but also the internal customer of the company.

The customer orientation of the personnel includes economic and social components. The economic values of customer orientation include wages and social benefits paid by the employer and material benefits provided by the retail chains to their employees. On the other hand, it is important to compare their wages with the performance of their work. The professionalism of employees depends on their education and practical experience. Employers invest in their training in order to achieve the purpose and intent. Social values should include the conditions that employers create for performance in the workplace, meeting work standards, functions, and being involved in creating consumer value.

A meaningful demonstration of customer orientation will be realized through compliance with the company's conditions related to its performance, the quality of the advices the company provides and liaison with employees, managers and customers, as well as strict adherence to the rules of business ethics, etc.

TABLE I. COMPONENTS OF EMPLOYEES CUSTOMER ORIENTATION

\begin{tabular}{|c|l|}
\hline $\begin{array}{c}\text { Demonstration } \\
\text { elements }\end{array}$ & \multicolumn{1}{|c|}{ Aspects of demonstration content } \\
\hline Service activities & $\begin{array}{l}\text { - compliance with warranty conditions; } \\
\text { - after-sales service; } \\
\text { - meeting delivery dates, etc. }\end{array}$ \\
\hline External image & $\begin{array}{l}\text { - compliance with appearance standards; } \\
\text { - following packaging display rules; } \\
\text { - compliance of offices, rooms and workplaces with } \\
\text { standards, etc. }\end{array}$ \\
\hline $\begin{array}{c}\text { Communication } \\
\text { image }\end{array}$ & - following business ethics regulation \\
\hline $\begin{array}{c}\text { Professionalism } \\
\text { - providing advice on product categories (services) } \\
\text { and trademarks; }\end{array}$ & $\begin{array}{l}\text { - using terminology related to product (service); } \\
\text { - informing about properties and functions of } \\
\text { product (service) }\end{array}$ \\
\hline $\begin{array}{c}\text { Relationship } \\
\text { stability }\end{array}$ & $\begin{array}{l}\text { - using technologies for building long-term } \\
\text { relationships }\end{array}$ \\
\hline
\end{tabular}

Note that supporters of the strategic human resources management concept, a key position of which is a strategic top-down correspondence between the business strategy and the human resource management strategy, made a certain contribution to the development of ideas about the relationship between the company's customer orientation, service value addition by retail chain and customer orientation of staff.

Customer orientation management as a subsystem of service management put by the retail chain in place is an important component. It takes into consideration micro-level factors that include the economic environment, legal institutions, social development, and geographical location. Mesofactors between the level are immediately the factors of direct influence on the retail chain including consumers, suppliers, competitors, the labor market, and banking services.

Having examined the relationship between customer orientation and the growth of retail chain services, we noted that the quality management system tools in place also play an important role. Quality management for retail chains allows to standardize and unify its services, since the location of retail facilities is wide geographical, therefore, corporate standards related to organizational and management matter provide the expected values of retail chain services in relation to all counterparties in the supply chain. 
*author's development

In view of the foregoing, the activities of a retail chain aimed at accounting and meeting the requests and requirements of consumers in terms of providing them with products and services of a higher level than those of competitors, i.e. having great consumer value, in the long run will attract new and retain regular customers, respectively, to ensure growth in sales and profits.

\section{ReSEARCH METHODOLOGY}

Currently, there is no single approach to assessing the customer orientation of company personnel, especially when it comes to employees working in branches of an international company in different countries. Their customer orientation can be influenced by such factors as the company's strategy [11], employee satisfaction with the work [12], application of the employee remuneration system in the company based on the assessment of customer satisfaction [13], etc. At the same time, the indicators of personnel customer orientation may include, among others, sales volume, the number of positive feedback from customers, the number of repeated customer calls to the company in order to purchase goods or services, etc. Most often, the customer orientation of personnel is recommended to assess by indicators of performance, behavior, motivation, values, attitudes, personal qualities, knowledge, and skills of staff [14, p.14-17].

When building a model of customer orientation management, it is necessary to take into account the risks in the activities of the retail chain $[16,17,18]$ as an external influence factor. Customer orientation of employees will correlate with performance indicators of the company [15].

Quantitative and qualitative data collection methods are usually used to assess customer orientation of employees. In this case, various groups of persons may act as respondents: company employees (e.g., representatives of sales departments, company's management), line managers, as well as clients of the company. In some cases, it is advisable to simultaneously conduct a survey of company employees and its customers, and then compare the results [15].

As part of scientific studies, questionnaires and interviews are often used as methods for collecting data and assessing customer orientation of staff [19].

In practice, methods such as tests (e.g., testing knowledge of service standards, product line and similar), "assessment centers", "secret visitor" methodology, questionnaire survey, focus group and others are usually used to assess customer orientation of staff.

The impact model assesses the impact of staff performance on an integrated indicator of the retail services effectiveness, reflecting the relationship between the material incentives matrix versus the employee's work contribution and its results through a dynamic assessment of labor productivity, labor quality, payroll, and the criterion of employees social efficiency in terms of retail chain services effective management:

$$
K_{\text {int }}=\sqrt[4]{\Delta K_{\text {rev. }} \times \Delta P_{\text {payroll }} \times \Delta P_{\text {tr.act } /} \times \Delta I_{\text {ret }}},
$$

where:

$\mathrm{K}$ int = integral indicator that assesses the impact of labor performance (customer orientation) of staff on the integrated indicator of the retail services effectiveness,

$\Delta \mathrm{K}$ rev. $=$ coefficient of change in the number of trade workers

$$
\begin{aligned}
& \Delta \mathrm{P} \text { payroll }=\text { payroll budget breakeven } \\
& \Delta \mathrm{P} \text { trading activities }=\text { trading activities breakeven }
\end{aligned}
$$

$\Delta \mathrm{I}$ return $=$ cost recovery

The impact model of the labor service management performance integrated indicator is evaluated by analyzing such indicators as productivity, labor quality and payroll using a complex indicator of their interaction level, which is expressed through an integral coefficient. Strengthening the relationship of material labor incentives and labor performance forms will make it possible for the trade business of the consumer cooperation system to regard the costs of its implementation in terms of evaluating their performance efficiency.

\section{RESUlTS}

The resulting relationship can appreciate the forms of material incentives and increase the employer's interest in improving the performance of their employees.

Taking into account the specifics of the retail chain services, the practical importance of customer orientation is realized through the creation of comfortable environment for the employee, and feedback from the consumers. For consumers, it is necessary to provide conditions for meeting their needs to consolidate financial activity. The table shows three important parameters: content, customer orientation, performance, creation of conditions for loyal employees, and customer loyalty, rated economic parameters for three models, the growth of retail chain with a focus on consumer value, orientation to a retail chain, and a participant in the consumer value chain. The proposed options for customer involvement in accordance with the price level are the basis for the growth of the retail chain.

\section{Areas of customer orientation management:}

\section{Building a customer orientation management team}

2. Assessment of consumer loyalty by point-by-point measurements using contact points and transactions that make it possible to assess the relationship of performance versus actions of employees.

\section{Voice of the Client Feedback Management}

Collect disparate data from feedback features (call center, Internet, mobile, face-to-face) to web analytics, data on client behavior, and information from social networks. Provide for real-time feedback processing and, most importantly, a quick solution to the difficulties your clients may have. The 


\section{DISCUSSION}

feedback system is a "compass of impressions" that guides the growth of customer orientation.

\section{Customer Feedback Measurement}

Measuring customer feedback is a systematic collection of feedback in the form of digital quantitative data. It makes it possible to track feedbacks and analyze the dynamics of success. Online surveys, store visits, personal and telephone interviews, devices at points of sale, mobile phones, interactive voice response (IVR) of call centers can be used for measurement.

\section{Designing the client feedback}

The ability to design a service process that delights, motivates and inspires clients is a vital component of customer feedback management. Significant changes — with the satisfaction of new customer needs and innovation. Designing the feedback includes investigating the audience of clients, advising and involving responsible employees, analyzing the existing customer journey and prioritizing tasks for completion, actual designing new feedbacks and reflecting them in the standards of work, developing a guide on the principles of feedback designing, training the team for feedback designing and building customer journey maps. Creating the customer journey map

6. The customer journey map is a visual representation of the customer's interaction with the company. Unlike the description of the business process, the customer journey map allows you to feel like you are the customer, see what challenges they are trying to solve, what barriers they face on the way, and what moments require changes. They show the client's actions, his/her impressions from the beginning to the end of interaction in different areas, units, devices and segments.

\section{Introduction of revisions}

This may be the development of an action plan for 24-36 months in conjunction with a customer orientation management team. The plan includes customer orientation management targets, sell programs, and economic evaluations. It requires the development of a performance evaluation program that includes benchmarks for the company, departments and employees in the field of customer orientation.

8. After launching the revisions and the pilot project, maintaining revisions and performance comes into the picture. First, the content on customer orientation for managers and employees, which may include informational resources and tutorials on the principles of work in the company, introductory training programs for new employees, social inclusion tools and game mechanics. Second, the communication plan is a guide for reporting customer relations in communication (internal and external) to customer orientation. Third, performance indicators and reports are concentrated information about customer satisfaction and employee engagement by business area and division.
Let us draw up a model of labor performance of a retail chain for the effectiveness of a trading service - the moving average method. Smooth the performance indicators according to table II.

TABLE II. INDICATORS THAT INFLUENCE THE LEVEL OF WAGES AS EXEMPLIFIED BY THE BAKHETLE RETAIL CHAIN

\begin{tabular}{|c|c|c|c|}
\hline $\begin{array}{c}\text { Timing } \\
\text { (year) }\end{array}$ & $\begin{array}{c}\text { Labor productivity, } \\
\text { Rubles }\end{array}$ & $\begin{array}{c}\text { Turnover, RUB } \\
\text { bn }\end{array}$ & Revenue, RUB bn \\
\hline 2011 & $993,052.00$ & 5.22 & 52.2 \\
\hline 2012 & $1,988,697.58$ & 6.66 & 87.36 \\
\hline 2013 & $3,121,764,71$ & 8.41 & 107.39 \\
\hline 2014 & $3,466,666.67$ & 9.02 & 117.5 \\
\hline 2015 & $3,842,248.01$ & 9.05 & 50.5 \\
\hline 2016 & $3,654,457.34$ & 9.35 & 42 \\
\hline 2017 & $3,748,352.675$ & 9.4 & 57.8 \\
\hline 2018 & $3,701,405.008$ & 9.6 & 62.3 \\
\hline
\end{tabular}

Using the method of exponential smoothing, let us make revision forecasting in the 3-year period of indicators of labor productivity, turnover, and profit.

The study has determined that under the traditional scenario for the growth of the Bakhetle company and the system of performance incentives for its employees, the forecast is not optimistic. A downward trend was determined for all three factors, and a slight decrease in labor productivity by $8.7 \%$ reduces the turnover of undertakings by an average of $12.9 \%$ while the profit by $1.5 \%$.

The practical interest of our study lies in the assessment and forecasting of the undertakings growth based on the results of labor processes and incentives standardization. Thus, according to the proposed system, first, the system of calculating the fixed official salary and the amount of bonuses becomes transparent. Subject to the quality performance of his/her duties, the employee can receive the salary that fully appreciates his/her contribution to the company.

As the study shows, there is a general increase in the performance indicators of Bakhetle, which we have taken as the main ones. The proposed system of accrual of salaries made it possible to increase the average wage from $18,890.3$ rubles to 24,931.1 rubles and optimally bring it closer to the average market. It seems possible to evaluate economic efficiency using a number of indicators proposed in this study (Table III):

TABLE III. EVALUATION OF THE STANDARDIZATION SYSTEM OF LABOR PROCESSES AND INCENTIVES

\begin{tabular}{|c|c|c|c|c|}
\hline \multirow{2}{*}{ Indicator } & \multicolumn{3}{|c|}{ Forecast period (year) } & $\begin{array}{c}\text { Average } \\
\text { forecast } \\
\text { value }\end{array}$ \\
\cline { 2 - 5 } & 2019 & 2020 & 2021 & 4.33 \\
\hline $\begin{array}{c}\text { Sales activity } \\
\text { breakeven, \% }\end{array}$ & 3.92 & 4.16 & 4.22 & $3,701,405$ \\
\hline $\begin{array}{c}\text { Labor productivity, } \\
\text { thousand rubles per } \\
\text { person }\end{array}$ & $3,654,457.34$ & $3,701,405$ & $3,748,352$ & 527.8 \\
\hline $\begin{array}{c}\text { Payroll, thousand } \\
\text { rubles per person }\end{array}$ & 527.8 & 527.8 & 527.8 & 4.153 \\
\hline $\begin{array}{c}\text { Coefficient of } \\
\text { social performance } \\
\text { of wages }\end{array}$ & 3.103 & 4.128 & 4.128 & \\
\hline
\end{tabular}


The wage of an employee in the retail chain will depend trading activities breakeven of the retail chain undertakings studied;

labor performance of trade workers;

payroll;

social indicator of wage efficiency.

Thus, it is clear that the proposed system of labor processes and incentives standardization fully justifies itself, and this despite the significant costs associated with its introduction, caused by the increase in employees' wages. Estimating the forecast values of indicators from 2019 to 2021, we can establish a general growth trend:

labor productivity level - by 3,701 thousand rubles;

trading activities breakeven by 1.96;

payroll for 313.32;

coefficient of social efficiency by 3.098 .

The system of standardization of labor processes and incentives, which we propose for implementation in Bakhetle, firstly, forms a sufficient level of wages, evaluates the personal and official qualities of the staff. Second, it forms a new level of labor relations. Third, it reduces the typical turnover of sales personnel. Therefore, based on the analysis of paragraphs 2.2. and 2.3, it was proposed and introduced to increase the average salary of sellers and cooks; functions of employees were clearly defined allowing to adhere to a certain standard of service.

The introduction of the standardization system of labor processes and incentives results in rise of the link between incentive measures and the economic sustainability of trading undertakings of the studied retail chains. The projected average wage will increase by $15.9 \%$, and the profit margin by $4 \%$. The breakeven indicator of retail chains will come up by 1.96 percentage points.

In 2018, as a proposal, an incentive system was introduced to the Bakhetle retail chain. It was also tied to the employee's personal contribution. Modern technologies make it possible to record the sales level of each department on a daily basis using the updated SAB program and expert guidance from senior managers. Accordingly, the more goods from this department were sold, the higher the bonuses will be given to the employees of this department. The following features of the incentive system are proposed:

To refuse the system of fines;

The work of each employee in the store and office will be evaluated. He/she is rated for the quality of work. The employee can see this assessment in his/her personal online account on the company web site (service site). For this purpose, the creation of a web site is proposed;

Service employees will receive additional bonuses for the quality of their performance;

It was proposed to create a special "best service site", on which each employee can go and see the results of their activities on the quality of service. on:

position tariff rate;

employee categories;

the number of hours worked for the payroll period.

The variable component of the remuneration is charged and paid based on the personal contribution of each employee and depends on the results of the store, the type of employee's participation in the trading process, and the performance evaluation directly by the manager.

The variable component should consist of two parts: the first component is paid for meeting the turnover plan, the second - for quality service and conscientious performance of official duties. Premiums for:

each year of work in the company in the amount of 5\%;

work on holidays and days before public holidays;

night work;

working conditions (e.g., handling dairy products at subzero temperatures);

combining duties, positions; for having a higher education degree.

This retail chain does not practice night margins on products. The Bakhetle chain has its own training center, which, along with direct training in classes, provides remote training to the employees. These are lectures, training seminars in a non-training format. Computer classes for training were equipped at the head Kazan training center and regional branches. Certification of personnel is also taking place in the remote format. Thus, an employee can complete more training programs in a year.

\section{CONCLUSION}

Customer orientation management as a subsystem of controlling the retail chain is an important component. It takes into consideration micro-level factors that include the economic environment, legal institutions, social development, and geographical location. Mesofactors between the level are immediately the factors of direct influence on the retail chain including consumers, suppliers, competitors, the labor market, and banking services. All of them influence the level of customer orientation of the retail chain and form aggregate consumer preferences. Customer orientation is essential in the trade sector since it is important to promptly respond to additional and new consumer requests, constantly have feedback from them, staff should be interested in the joint creation of value, motivated and involved in all management processes of the distribution network.

\section{References}

[1] Lockwood, Nancy R. "Leveraging Employee Engagement for Competitive Advantage: HR's Strategic Role." HRMagazine Mar. 2007, pp. 1-11 
[2] Parasuraman A., Zeithaml V., Berry L. SERVQUAL: A Multiple-Item Scale for Measuring Consumer Perceptions of Service Quality. Journal of Retailing. 1988, vol. 64, 1, pp. 12-40

[3] Kotler, F. Marketing Management. $2^{\text {nd }}$ Edition. Saint Petersburg: Piter. 2006, pp. 464.

[4] Saxe, R. and Weitz, B.A. "The SOCO scale: a measure of the customer orientation of salespeople", Journal of Marketing Research. 1982, vol. 19, pp. 343-51.

[5] Bateson, J.E.G. Managing Services Marketing, Text and Readings, 2nd ed., The Dryden Press, Chicago, IL. 1992.

[6] Berry, L.L., Shostack G.L., Upah G.D. Relationship Marketing. Emerging perspectives on service marketing. New York: Harper and Bros. 1983, pp. 58-70

[7] Homburg, Ch., Muller M., Klarnn M. When does salespeople's customer orientation lead to customer loyalty? The differential effects of relational and functional customer orientation. Journal of the Academy of Marketing Science. 2011, vol. 39, 6, December, pp. 795812.

[8] Brown A., Ickes B, Ryterman R. The myth of monopoly: a new view of industrial structure in Russia. Pennsylvania State University. Department of Economics Paper. 1993, 10935. URL: http://econ.la. psu.edu/ bickes/indcon.pdf.

[9] Kara, A., Andaleeb S.S., Turan M., Cabuk S. An examination of the effects of adaptive selling behavior and customer orientation on performance of pharmaceutical salespeople in an emerging market. Journal of Medical Marketing. 2013, 13(2), pp. 102-114.

[10] Donavan, D.T., Brown T.J., Mowen J.C. Internal benefits of service worker-customer orientation: job satisfaction, commitment, and organizational citizenship behaviors 156. Journal of Marketing. 2004, vol. 68, 1, January, pp. 128-146.

[11] Strong, C.A., Harris, L.C. The drivers of customer orientation: an exploration of relational, human resource and procedural tactics. Journal of Strategic Marketing. 2004, 12. pp. 183-204.

[12] Gountas, S., Gountas, J., Mavondo, F.T. Exploring the associations between standards for service delivery (organisational culture), coworker support, self-efficacy, job satisfaction and customer orientation in the real estate industry. Australian Journal of Management. 2014, 39(1), pp. 107-126.

[13] Widmier, S. The effects of incentives and personality on salesperson's customer orientation. Industrial Marketing Management. 2002, 31, pp. 609-615.

[14] Shavrovskaya, M. N. Customer orientation of staff: formation and assessment. Candidate's thesis. Omsk. 2011, 22.

[15] Deshpande, R., Farley, J.U., Webster, F.E.Jr. Corporate culture, customer orientation, and innovativeness in Japanese firms: a quadrad analysis. Journal of Marketing. 1993, vol. 57, 4, pp. 23-7.

[16] Fakhrutdinova Liliya R., Eidelman Boris M., Bunakov Oleg A., Creation of the effective enterprise in the tourist market/IIOAB Journal. 2019, vol.10, pp. 118-121.

[17] Ajupov, A., Sherstobitova A., Syrotiuk S., Karataev A. The riskmanagement theory in modern economic conditions. E3S Web of Conferences. 2019. 110, 02040.

[18] Sharafutdinova N., Valeeva J. Quality management system as a tool for intensive development of trade organizations. Mediterranean Journal of Social Sciences. 2015, 6(1S3), pp. 498.

[19] Alexsandr S. Kuznetsov. Russian Professor's meeting. Russian Journal of Physical Education and Sport. 2019, 14(1), pp. 17-22. DOI: 10.14526/2070-4798-2019-14-1-18-24 